\title{
Analysis of the use of Kinect technology as a therapeutic alternative to improve physical capacities in older adults
}

\section{Análisis del uso de la tecnología Kinect como alternativa terapéutica para mejorar las capacidades físicas en los adultos mayores}

\author{
CERVANTES-CASTILLO, Sebastián†**, DÍAZ-ARCOS, Francisco Vertin, SERRANO-GUTIERREZ, \\ Maximiliano and MORALES-OTERO, Sandra
}

Universidad del Valle de México, Campus Cuernavaca, Escuela de Ciencias de la Salud. Fisioterapia, Mexico.

ID $1^{\text {st }}$ Author: Sebastián, Cervantes-Castillo / ORC ID: 0000-0002-6819-0694, airXiv Author ID: Sebas.cc

ID $1^{\text {st }}$ Co-author: Francisco Vertin, Díaz-Arcos / ORC ID: 0000-0003-1134-5410, airXiv Author ID: franciscoVertin

ID $2^{\text {nd }}$ Co-author: Maximiliano, Serrano-Gutierrez / ORC ID: 0000-0002-1308-1618, airXiv Author ID: MaximilianoSerrano

ID $3^{\text {rd }}$ Co-author: Sandra, Morales-Otero / ORC ID: 0000-0002-9457-6611, airXiv Author ID: moos1203

DOI: $10.35429 / J P .2021 .13 .5 .5 .10$

Received January 15, 2021; Accepted June 30, 2021

\begin{abstract}
The present study aims to describe the efficacy of Kinect technology for the therapeutic rehabilitation of geriatric patients by conducting and analyzing a 8-session therapeutic program based on this technology in which 12 study subjects participated, 8 Male subjects and 4 female subjects, within the physical capacities, the muscular strength was evaluated in the Daniels scale of the flexion of the hip, knee, shoulder and elbow and the goniometry of the flexion / extension of these same members. A greater elasticity and mobility were observed by female subjects apart from a greater increase in the range of motion in the same period of time than Male subjects, with respect to muscle strength, it was not possible to demonstrate a significant advance so the effectiveness of Kinect therapy in this area still shows contrasts in its results. Objective: to describe the efficacy of kinect technology for the therapeutic rehabilitation of elderly patients by carrying out and analyzing a therapeutic program. Methodology: analysis of the results obtained after several sessions of application of the games of the Xbox 360 console with Kinect control.
\end{abstract}

Kinect, Rehabilitation, Physical capacities

\section{Resumen}

El presente estudio tiene como objetivo describir la eficacia de la tecnología Kinect para la rehabilitación terapéutica de pacientes geriátricos mediante la realización y análisis de un programa terapéutico de 8 sesiones basado en esta misma tecnología en el que participaron 12 sujetos de estudio, 8 sujetos masculinos y 4 sujetos femeninos, dentro de las capacidades físicas, la fuerza muscular se evaluó en la escala de Daniels de la flexión de cadera, rodilla, hombro y codo y la goniometría de la flexión / extensión de estos mismos miembros. En los sujetos femeninos se observó una mayor elasticidad y movilidad además de un mayor aumento en el rango de movimiento en el mismo período de tiempo que los sujetos masculinos, con respecto a la fuerza muscular, no fue posible demostrar un avance significativo por lo que la efectividad de la terapia Kinect en esta área todavía muestra contrastes en sus resultados. Objetivo: describir la eficacia de la tecnología kinect para la rehabilitación terapéutica de pacientes de la tercera edad mediante la realización y análisis de un programa terapéutico. Metodología: análisis de resultados obtenidos tras diversas sesiones de aplicación de los juegos de la consola Xbox 360 con control Kinect.

Kinect, Rehabilitación, Capacidades físicas

Citation: CERVANTES-CASTILLO, Sebastián, DÍAZ-ARCOS, Francisco Vertin, SERRANO-GUTIERREZ, Maximiliano and MORALES-OTERO, Sandra. Analysis of the use of Kinect technology as a therapeutic alternative to improve physical capacities in older adults. Journal of Physiotherapy and Medical Technology. 2021. 5-13:5-10.

\footnotetext{
* Author Correspondence (E-mail: A900067509@my.uvm.edu.mx).

$\dagger$ Researcher contributing as first author.
} 


\section{Introduction}

Physiotherapy aims to improve the quality of life of the human being who suffers from certain diseases both in the prevention of degenerative diseases as it happens in the elderly, for the WHO the term older adult refers to any person, whether male or female over 60 years. Although this is seen simply as a legal limit, there may be many physical and biological factors that can alter the characteristics of an elderly person, such as degenerative diseases caused by bad habits such as sedentary lifestyles that cause loss of mechanical functions, fragilization due to osteopenia, progressive deterioration of the qualities of tendons and ligaments, alteration of collagen, decrease in joint flexibility and alterations of spinal statics [8] causing the decrease or loss of movement, either by pathology or disuse [3], in Mexico alone according to data from the National Institute of Statistics and Geography (INEGI) in 2020 there are more than 15 million people aged 60 years or older of which $52 \%$ have some limitation or disability representing $0.63 \%$ of the total Mexican population, in Morelos they represent $8 \%$ of the total population of the state.

The integration of physical activity in the elderly for the prevention of pathologies and the improvement of physical capacities can be tedious for the elderly since the therapy turns out to be repetitive and boring. [1] Therefore, the implementation of technology such as the "Kinect" as an inclusive therapeutic alternative, since it works with body gestures, in addition to motivating and generating interest in the older adult through competition, fun and physical activity.

\section{Development}

An analysis was made about the acceptance and benefits that this type of therapeutic alternative generates. The research was developed in the rehabilitation area of the ISSFAM (Social Security Institute for the Mexican Armed Forces) home where 25 elderly residents attend, of which 12 elderly adults decided to participate voluntarily in the project $(5$ dependent for mobility and transportation, 7 independents for daily life activities) (see table 1). The games "dance central 2" and "Kinect sports" were used to achieve an approach and interaction of this group with technology.
Thanks to the Kinect motion sensor developed by Microsoft studios we can have a more natural interaction between people and technology due to its interface with movement commands (dance movements, jumping, throwing a punch, hitting a racket, kicking a ball) that are captured by infrared signals that the device sends and are read by the RGB (Red, Green and Blue) camera, on the other hand it captures the voice with an integrated microphone and a modern software with a customized processor that facilitates control and recognition by users making it a more inclusive tool.

\begin{tabular}{|c|c|c|c|c|c|}
\hline Patient & Gender & Age & Height & Weight & Cause of disability \\
\hline $1 \mathrm{EM}$ & Male & 84 & 1.76 & 83 & $\begin{array}{l}\text { Physiological loss due to } \\
\text { age, degenerative } \\
\text { diseases (osteoarthritis), } \\
\text { inactivity. }\end{array}$ \\
\hline $2 \mathrm{RG}$ & Male & 79 & 1.57 & 64 & $\begin{array}{l}\text { Poor } \\
\text { management of left } \\
\text { lower limb, inactivity } \\
\text { and physiological loss } \\
\text { due to age. }\end{array}$ \\
\hline $3 \mathrm{MG}$ & Male & 68 & 1.69 & 75 & $\begin{array}{l}\text { Bullet impact in spinal } \\
\text { cord at L3 and L4. }\end{array}$ \\
\hline $4 \mathrm{TC}$ & Male & 78 & 1.73 & 89 & $\begin{array}{l}\text { Physiological loss due to } \\
\text { age, renal insufficiency, } \\
\text { diabetes, muscle } \\
\text { weakness. }\end{array}$ \\
\hline $5 \mathrm{MS}$ & Male & 76 & 1.52 & 62 & $\begin{array}{l}\text { Physiological loss due to } \\
\text { age, ischemic stroke. }\end{array}$ \\
\hline 6DT & Male & $\overline{72}$ & 1.68 & 79 & \\
\hline $7 \mathrm{FE}$ & Male & 65 & 1.55 & 82 & \\
\hline $8 \mathrm{LC}$ & Female & 66 & 1.62 & 74 & \\
\hline 9ST & Female & 64 & 1.58 & 77 & \\
\hline $10 \mathrm{MF}$ & Male & 68 & 1.71 & 88 & \\
\hline $11 \mathrm{VC}$ & Female & 75 & 1.61 & 62 & \\
\hline $12 \mathrm{MC}$ & Female & 71 & 1.56 & 71 & \\
\hline
\end{tabular}

Table 1 Patient characteristics

\section{Methodology}

Method: analysis of results obtained after several sessions of application of the Xbox 360 console games with Kinect control:

Research focus: this research is focused on older adults and their physical activity, we seek to know how this type of innovative technique helps to improve their physical capabilities (specifically the ranges of joint movement and muscle strength per segment), what are the advantages in applying this technique as a rehabilitation method and see if the results have sufficient relevance to be able to substantiate its effectiveness.

\section{Types of research}

Inductive: the behavior and the way in which people performed the activity were observed. 
Casi-experimental: where we worked on new ways of doing physical activity and motivating people regardless of their limitations or conditions.

Explanatory: we seek to know if the sedentary lifestyle in this type of people is caused simply by the deterioration caused by old age or if other external factors cause this situation in the elderly.

\section{Levels of research}

- Exploratory: the aim is to analyze the phenomenon of sedentary lifestyles and identify how it can become a public health problem.

Descriptive: the main reasons for sedentary lifestyles and how they affect health are described.

Relational: we sought to identify how sedentary lifestyles degrade the physical and cognitive condition of older adults.

\section{Modalities of the research}

The research was mainly in the field applying this method of physical activation but we also relied on the principles of exercise physiology thanks to books and articles where they focus on the benefits of physical activity in people and the physiological changes it can cause in people

\section{Population and sample}

The study was conducted in 12 elderly people ( 8 men and 4 women) where 5 of them were with high physical limitation so they have to be in wheelchair the other 7 did not have severe physical limitations, but they were not in optimal conditions to perform physical activity.

\section{Variables}

\begin{tabular}{|l|l|l|}
\hline \multicolumn{2}{|c|}{ Variables } & \multicolumn{1}{c|}{$\begin{array}{c}\text { Conceptual } \\
\text { definition }\end{array}$} \\
\hline Age & $\begin{array}{l}\text { Time that a } \\
\text { person or other } \\
\text { divinition }\end{array}$ \\
\hline Gender & $\begin{array}{l}\text { lived years - 84 has } \\
\text { lived, counting } \\
\text { from birth. }\end{array}$ & \\
years & $\begin{array}{l}\text { The set of } \\
\text { people or things } \\
\text { that have } \\
\text { common female } \\
\text { general } \\
\text { characteristics. }\end{array}$ & \\
\hline
\end{tabular}

\begin{tabular}{|c|c|c|}
\hline Mobility range & $\begin{array}{l}\text { It is the } \\
\text { maximum angle } \\
\text { described } \\
\text { between two } \\
\text { segments of the } \\
\text { body with a } \\
\text { reference plane, } \\
\text { which is } \\
\text { realized by } \\
\text { means of joints, } \\
\text { that is, it is the } \\
\text { number of } \\
\text { degrees through } \\
\text { which a joint is } \\
\text { able to move. }\end{array}$ & Goniometry \\
\hline Strength & $\begin{array}{l}\text { Muscular } \\
\text { strength is the } \\
\text { capacity to } \\
\text { generate } \\
\text { intramuscular } \\
\text { tension in the } \\
\text { face } \\
\text { resistance, } \\
\text { regardless of } \\
\text { whether or not } \\
\text { movement is } \\
\text { generated. In } \\
\text { other words, it is } \\
\text { the ability to lift, } \\
\text { push or pull a } \\
\text { given weight in } \\
\text { a single } \\
\text { movement with } \\
\text { the help of the } \\
\text { muscles. }\end{array}$ & Daniels's scale \\
\hline Play & $\begin{array}{l}\text { Play is an } \\
\text { activity that has } \\
\text { an end in itself, } \\
\text { that is, the } \\
\text { individual } \\
\text { performs the } \\
\text { activity itself in } \\
\text { order to achieve } \\
\text { the objective, } \\
\text { which is to be } \\
\text { pleasurable. }\end{array}$ & $\begin{array}{lr}\text { Kinect } & \text { sports } \\
\text { and } & \text { dance } \\
\text { central 2 } & \end{array}$ \\
\hline
\end{tabular}

Table 2 Variables

\section{Hypothesis}

"Exercises performed through video games will generate a significant change in the participants' ranges of motion and strength due to the fact that it will encourage regular and continuous physical activity".

\section{Materials}

Vivid bright projector: a projector was used to make the image clearer and easier to see for the participants as well as making the activity more interactive and interesting.

CERVANTES-CASTILLO, Sebastián, DÍAZ-ARCOS, Francisco Vertin, SERRANO-GUTIERREZ, Maximiliano and MORALESOTERO, Sandra. Analysis of the use of Kinect technology as a therapeutic alternative to improve physical capacities in older adults. Journal of Physiotherapy and Medical Technology. 2021 
- Xbox 360 was the ideal console for the research due to its easy access and simple software that allows easy operation.

Kinect motion sensor: the most vital tool of the research thanks to its motion detection capability.

Dance central 2 game: a dance game with different levels that adapt to the players' needs.

- Kinect sport game: a sports game with several mainly competitive activities ideal to encourage interest.

- $\quad$ Attendance logbook: used to keep track of attendance.

Goniometer: it is an essential tool for the evaluation of joint ranges at the beginning and end of the research.

- Daniels's scale: it is a highly adaptable scale that provided us with information about the participants' muscle strength at the beginning and end of the research.

\section{Procedure}

A physical evaluation was made to each participant in which aspects such as ranges of motion and muscle strength in both lower and upper limbs were taken into account, once the measurements were made the results were emptied in a record that will serve later to make a comparison, in the case of people in wheelchairs the evaluation in lower limbs is omitted since we only work with upper limbs. For the evaluation of muscular strength we used the Daniels scale which is divided into 6 levels of physical capacities, in our investigation most of the participants were between level 3 and 4, in the goniometry all the participants presented limitations in both limbs, but their range of movement is functional.

The older adults were divided into groups of 2 to perform these activities, which consisted of two phases:

1. Adaptation to body movement by means of the Kinect.

2. Playing the game
Once they adapted to the use of the technology, the game was performed with a duration between 5-20 min depending on the game they decided, where they followed the specific body patterns of each game.

\section{Results}

Statistically significant differences $(\mathrm{p}<0.05)$ were observed in the pretest and posttest knee goniometry results between men and women.

The men's knee goniometry in the first assessment was 2.33 which improved to a score of 2.66, while the women started with a score of 6.5 and this improved to a score of 8.25, reflecting a much more accentuated increase in the female group in spite of having had better knee goniometry scores from the beginning (see table 3).

\begin{tabular}{|c|c|c|c|c|c|c|}
\hline & \multicolumn{2}{|c|}{ Men } & \multicolumn{2}{|c|}{ Women } & \multicolumn{2}{|c|}{ All } \\
\hline & Before & After & Before & After & Before & After \\
\hline Elbow & $\begin{array}{l}90.75 \pm \\
45.92\end{array}$ & $\begin{array}{l}115.62 \\
\pm 15.96 \\
\end{array}$ & $\begin{array}{l}104 \pm \\
39.99\end{array}$ & $\begin{array}{l}114 \pm \\
22.46\end{array}$ & $\begin{array}{l}95.16 \pm \\
42.67\end{array}$ & $\begin{array}{l}115.08 \\
\pm 17.33 \\
\end{array}$ \\
\hline Shoulder & $\begin{array}{l}10.25 \pm \\
5.25\end{array}$ & $\begin{array}{l}11.37 \pm \\
4.59\end{array}$ & $\begin{array}{l}13.25 \pm \\
2.98\end{array}$ & $\begin{array}{l}15.75 \pm \\
1.25\end{array}$ & $\begin{array}{l}11.25 \pm \\
4.71\end{array}$ & $\begin{array}{l}12.83 \pm \\
4.30\end{array}$ \\
\hline Hip & $\begin{array}{ll}3.66 & \pm \\
3.05 & \\
\end{array}$ & $4 \pm 3$ & $\begin{array}{ll}7 & \pm \\
2.94 & \\
\end{array}$ & $\begin{array}{ll}7.75 & \pm \\
3.40 & \\
\end{array}$ & $\begin{array}{ll}5.57 & \pm \\
3.25 & \\
\end{array}$ & $\begin{array}{ll}6.14 \pm \\
3.57 \\
\end{array}$ \\
\hline Knee & $\begin{array}{ll}2.33 & \pm \\
1.57 & \\
\end{array}$ & $\begin{array}{l}2.66 \pm \\
1.57\end{array}$ & $\begin{array}{l}6.5 \pm \\
1.29 \#\end{array}$ & $\begin{array}{l}8.25 \pm \\
1.5 \#\end{array}$ & $\begin{array}{ll}4.71 & \pm \\
2.56 & \end{array}$ & $\begin{array}{l}5.85 \pm \\
3.28 \\
\end{array}$ \\
\hline
\end{tabular}

Table 3 Goniometry score of the patients by sex

Likewise, in a clinical manner, general improvements are observed in the goniometry results (score obtained based on our own scoring units related to the goniometry of knee extension and minimum and maximum knee flexion within the scores achieved by all patients) in the 4 joint groups evaluated between the first evaluation prior to the beginning of the therapeutic plan and the last evaluation made at the end of the therapeutic plan, presenting a notable increase in their ranges of mobility, which vary between 3 and 6 degrees of increase. (see graphics 1-4)

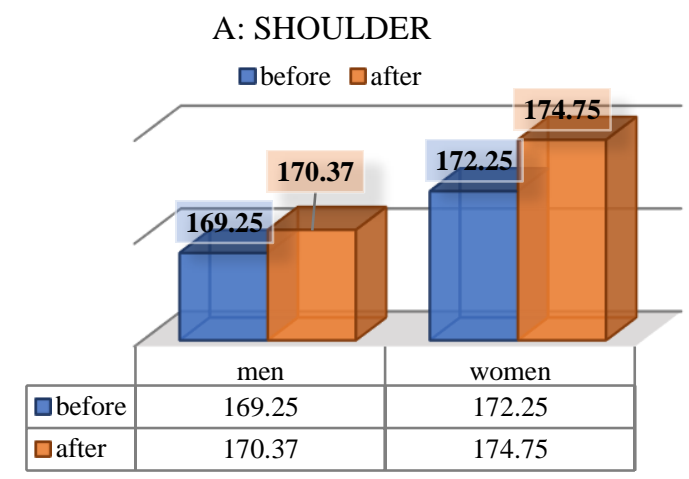

Graphic 1 Shoulder goniometry

CERVANTES-CASTILLO, Sebastián, DÍAZ-ARCOS, Francisco Vertin, SERRANO-GUTIERREZ, Maximiliano and MORALESOTERO, Sandra. Analysis of the use of Kinect technology as a therapeutic alternative to improve physical capacities in older adults. Journal of Physiotherapy and Medical Technology. 2021 


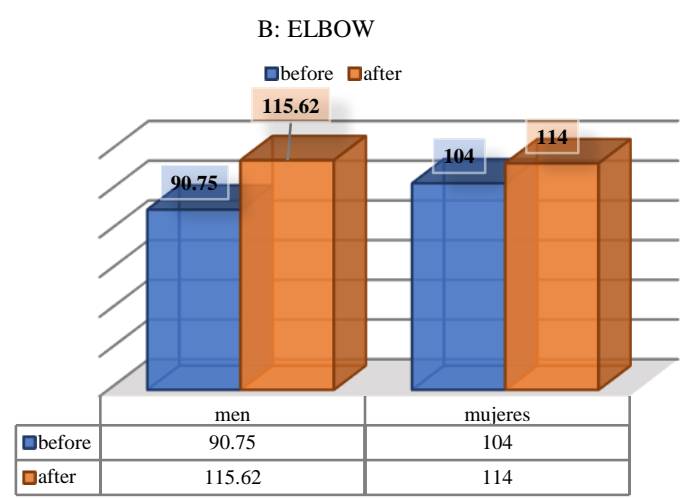

Graphic 2 Elbow goniometry

\section{C: HIP}

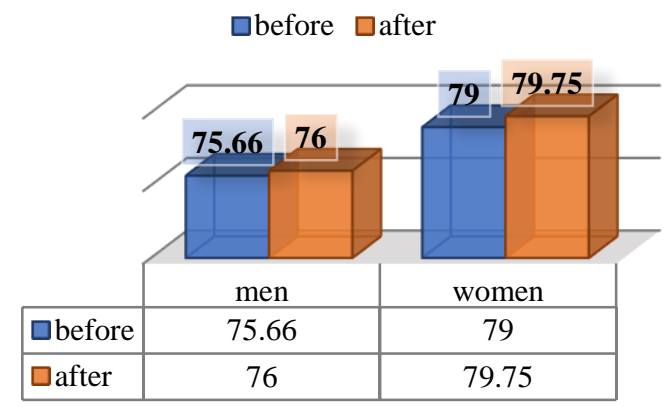

Graphic 3 Goniometry hip

\section{D: KNEE}

$\square$ before $\square$ after

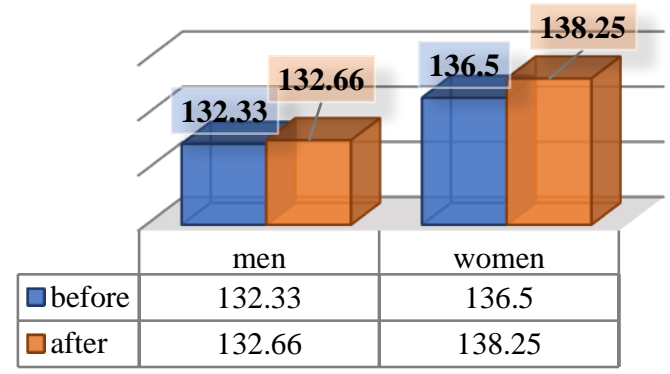

Graphic 4 Knee goniometry

No statistically significant differences were found in the muscle assessment results; however, there was an improvement of at least one point on the Daniels scale in $50 \%$ of the study subjects (6 of 12 patients).

Of the 6 study subjects who showed at least one point of improvement on the Daniels scale, 3 were male and 3 were female, however, of the 8 male study subjects in this study only 3 showed improvement $(37.5 \%)$ while of the 4 female study subjects 3 showed improvement $(75 \%)$. (see table 4$)$

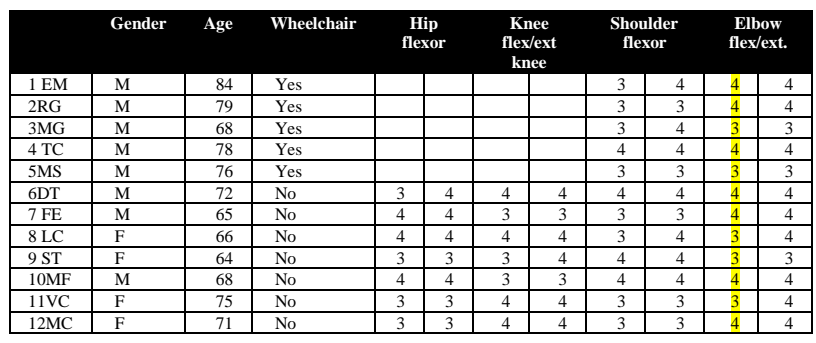

Table 4 Strength in Daniels scale before and after the therapeutic plan

\section{Acknowledgments}

We thank the institutions that were part of the research, as well as the people who participated and helped in the elaboration of this study.

\section{Conclusion}

The 12 study subjects showed an extremely positive result both in the improvement of ranges of motion and muscle strength, as well as the interest in performing the activities through the Kinect, since they are activities that generate attention due to their innovation, fun and creativity, and do not fall into monotony, which was the main reason why the adults in the nursing home stopped going to therapies and/or performing physical activities.

Regarding the ranges of motion of the study subjects, they increased up to 10 percent with respect to their original range prior to the study.

Knee goniometry in relation to men and women, before and after the therapeutic plan, showed a greater elasticity and mobility on the part of women as well as a greater range of movement in the same period of time, a fact that has already been evidenced by previous studies pointing out this greater mobility of women in relation to men. Regarding muscle strength, there was a lower response in the Daniels scale in $50 \%$ of the patients (6 of 12) of one point according to the mentioned scale, however 1 of the 12 subjects showed improvement in more than one item.

The study showed that the therapeutic alternative with Kinect alone is not such an effective therapeutic tool to increase muscle strength because it did not generate sufficient muscular stress to increase the strength of the extremities; however, it is a good therapeutic alternative to increase ranges of motion. 
The study could be improved by carrying out the same study with more time and sessions to observe if it is really possible to increase muscular strength or if the scope of this therapeutic method is limited to increasing the ranges of movement.

\section{References}

1. Muñoz-Cardona, J. E., Henao-Gallo, O. A., \& López-Herrera, J. F. (2013). Sistema de Rehabilitación basado en el Uso de Análisis Biomecánico y Videojuegos mediante el Sensor Kinect.

2. Pazán Jurado, L. R. (2015). Videojuegos de entrenamiento cerebral como factores de estimulación de la esfera cognitiva en $\ll<<<<<$ adultos mayores en el Centro Geriátrico Sagrado Corazón de Jesús (Bachelor's thesis, Universidad Técnica de Ambato-Facultad de Ciencias de la SaludCarrera de Psicología Clínica).

3. LÓPEZ-GONZÁLEZ, Erika*†, ALEJOELEUTERIO, Roberto, ANTONIOVELÁZQUEZ, JyAMBRIZ-POLO, J.. (Julio 20, 2016). Estudio de movimiento para la rehabilitación de enfermedades osteomusculares en adultos mayores con modelo virtual. Tecnología e innovación, vol. 3, 7-15.

4. Peralta Galarza, G. E., \& Tomalá Perero, J. D. (2018). Promoción de un estilo de vida saludable del club de adultos mayores. Centro de salud tipo c Venus de Valdivia 2017 (Bachelor's thesis, La Libertad: Universidad Estatal Península de Santa Elena, 2018.).

5. Troncoso-Pantoja, C., \& ValdebenitoMardones, M. (2019). Interpretación de la percepción en la realización de actividad física para un grupo de adultos mayores. Index de Enfermería, 28(1-2), 33-36.

6. Padilla, G. (2006). Calidad de vida y estrategias de afrontamiento ante problemas y enfermedades en ancianos de la ciudad de México. Universitas Psychologica, 501
7. J. A. P. Barbosa Murillo, N. G. Rodríguez M., Y. M. Hernández H. de Valera, R. A. Hernández H. y H. A. Herrera M.. (2007). Masa muscular, fuerza muscular y otros componentes de funcionalidad en adultos mayores institucionalizados de la Gran Caracas-Venezuela. 2021, de Scielo Sitio web:

https://scielo.isciii.es/scielo.php?pid=S02 $12-$

$16112007000700009 \&$ script=sci_arttext \&tlng=en

8. G. Kemoun, J. P. Rabourdin. (2009). Reeducación en geriatría. Enciclopedia Medico-Quirúrgica, 30, 1-11.

9. INEGI. (2020). Porcentaje de la población con algún tipo de discapacidad por grupo de edad. 08/10/21, de Instituto Nacional de Estadística y Geografía Sitio web: https://www.inegi.org.mx/temas/discapaci dad/\#Informacion_general 